「学会賞」紹介

\title{
非線形動的粘弾性測定に基つくく 繊維・高分子材料の疲労寿命の予知解析
}

\section{1. 緒 言}

材料に繰り返し変形を印加すると材料の構造や物性が 変化してついには破壊に至る。この現象は疲労と呼ばれ 材料に起因する事故の最も大きな原因の一つとなってい る. 金属材料の場合, 材料の疲労に起因する事故などが 報告され，疲労は大きな社会問題となっている1).

繊維・高分子材料が構造材料として用いられる場合, 疲労は材料の安全性と関連して極めて重要な物性となり, 疲労機構の解明と疲労寿命の予知解析は極めて重要な研 究課題である. 従来, 㵶維・高分子材料の疲労の研究分 野では, 試料に加える歪み振幅あるいは応力振幅と疲労 寿命の関係をプロットし, 材料の疲労特性を評価すると いうSーN曲線法やクラックの成長速度を測定する破壊力 学的な手法が適用されてきたが2),これらの研究例では緎 維・高分子材料に特有な高次構造や粘弾特性がほとんど 考虑されていなかった. 本稿では, 瀻維・高分子材料の 疲労挙動を最も顕著に反映する非線形動的粘弾特性測定 に基つくく纎維・高分子材料の疲労挙動の解析と疲労寿命 の予知解析について筆者らの研究成果を解説する.

\section{2. 疲労過程における動的粘弾性变化と疲労破損様式}

纎維・高分子材料は粘弾的性質を示し, それは温度, 周波数, 歪速度に強く依存する. 周期的な繰り返し変形 下での粘弾的エネルギー損失は試料の表面温度上昇と最 終的な疲労破壊へと導く不可逆的な構造変化をもたらし, 疲労挙動と密接に関連している. 疲労過程における動的
粘弾性変化と試料表面温度上昇を連続測定するための粘 弾性追随型疲労試験機を試作し, 疲労過程における動的 粘弾性変化と疲労挙動の関係について検討した 労試験機では, 試験片に一定振幅の正弦的変位を与え, 刺激である動的歪信号をモニターし, 応答である動的応 力信号を応力七ンサーで検出し, さらに繰り返し変形下 における試料表面温度, $\theta$ を表面温度計でその場測定する. 応力と歪みの信号の振幅の比より複素動的弾性率の絶対 値, $\left|E^{*}\right|$ をまた応力と歪みの位相差より力学的損失正接, $\tan \delta$ 疲労中連続的に評価する.

疲労過程における動的粘弾性関数と $\theta$ の測定をガラス状 態の可塑化ポリ塩化ビニル (p-PVC : 10phrのDOA(ジオ クチルアジペート)を含む) ${ }^{3)}$, 結晶性高分子の高密度ポリ エチレン $(\mathrm{HDPE})^{4)}$ とその配向物 ${ }^{5 \sim 7}$, ポリブチレンテレ フタレート $(\mathrm{PBT})^{8)}$ およびナイロンとその複合材料 ${ }^{9212)}$, エラストマーであるセグント化ポリウレタンウレア $(\mathrm{SPUU})^{13,14)}$ とスチレンーブタジエンースチレントリブロ ック共重合体 $(\mathrm{SBS})^{13)}$, 生体材料の犬緻密骨 ${ }^{15)}$ の各試料 について行った. Fig.1はE', $\tan \delta$ 及び表面温度上䄯, $\theta\left(=\mathrm{T}_{\mathrm{S}}-\mathrm{T}_{0} ; \mathrm{T}_{\mathrm{S}}\right.$ : 表面温度, $\mathrm{T}_{0}$ : 周囲温度)の疲労時間 依存性を脆性破損と延性破損について模式的に示したも のである，小さい動的歪振幅, 低周囲温度あるいは周囲 媒体への放熱が良好な場合には疲労初期過程で定常温度 に到達し, E’と $\tan \delta は$ 破損に至る直前まで一定値を示し, 疲労破損直前でE'が極大を, $\tan \delta か ゙$ 極小を示し, 極めて 弾性的な状態で試料が破断する脆性破損が観察された. この過程の大部分はクラックが巨視的に成長していない

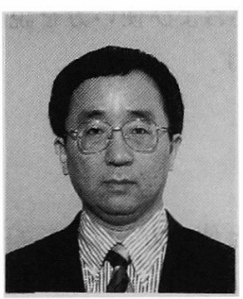

Analysis of Fatigue Lifetime of Polymeric Fibers and Polymeric Solids in Terms of Nonlinear Dynamic Viscoelastic Measurements 著者紹介 ATSUSHI TAKAHARA

Kyushu University, Institute for Fundamental Research of Organic Chemistry 九州大学有機化学基礎研究センター 分子システム化学部門 教授 工学博士

著者は, 高分子物性, 高分子表面科学, 集合分子科学を専門とされ, 馀維学会「櫻田武」記念賞 (1993年), 日 本レオロジー学会有功賞 (1995年), 馀維学会賞 (1999年)を受賞されている. 著書に,「高分子の力学物性」(共著, 共立出版, 1996年), 「大学院高分子科学」(共著, 講談社サイエンティフィック, 1997年)がある.

本稿では、織維・高分子材料の疲労挙動を最も顕著に反映する、非線形動的粘弾性測定に基つく截維・高分子 材料の疲労挙動の解析と, 疲労寿命の予知解析についての研究成果を解説していただいた. 


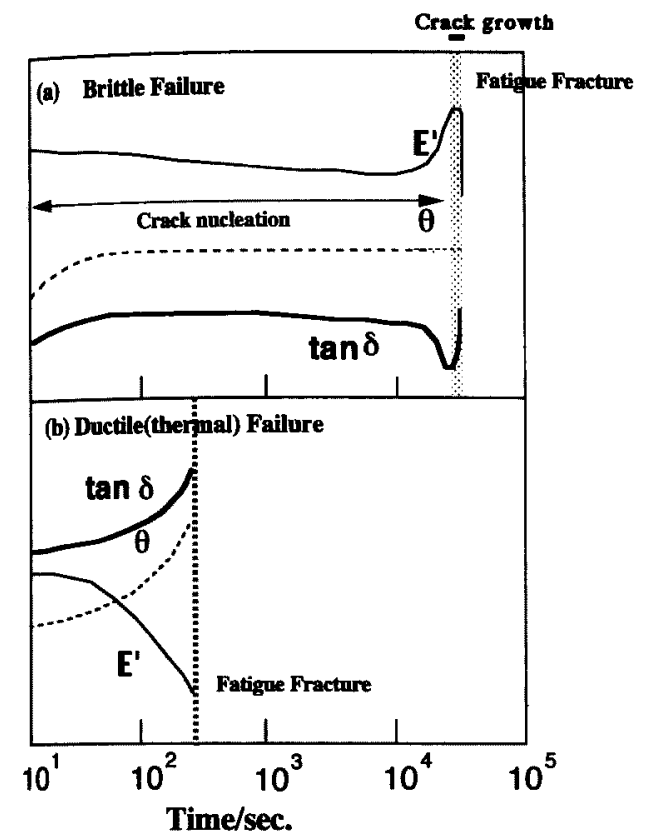

Fig. 1 Schematic representation of variations of $E^{\prime}$ $\tan \delta$, and surface temperature increase, $\theta$ with time during the fatigue process for (a) brittle and (b) ductile (thermal) failures.

段階で,クラックの急速な成長はE'の極大直後に起こって

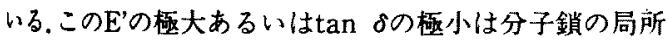
的な配向,あるいはphysical agingに対応していると考え られる。一方，大きな動的歪振幅，高周囲温度あるいは 断熱的な条件では, $E^{\prime} の$ 減少, $\tan \delta の$ 增加, 試料の温度 上开過程で試料が破断する延性破損が観測され，破断面 の塑性変形が影著であった. 特に, 室温より $20 〜 40 \mathrm{~K}$ 高温 僋に $\alpha_{\mathrm{a}}$ 吸収温度を有するガラス状高分子の場合，室温で の度労試駼でも試料温度が $\alpha_{\mathrm{a}}$ 吸収温度に到達し、試料が 著しい軟化を示す熱破損と呼ばれる現象が観測された。 このように疲労過程における動的粘弾性と試料表面温度 変化の測定に基づき，疲労破壊機構を分類できることが 明らかになった。

\section{3. 疲労破壊の規準式 ${ }^{3 \sim 14)}$}

高分子材料に繰り返し変形を加えると、試料の粘弾的 性質のために発熱が起こク，試料温度が上㫒する，疲労 中の試料温度上㫒から，疲労過程の試料の温度上界に相 当する疲学発熱量, $H_{H}$ と, 粘弾性的に評洒きれるエネル キー損失量 Hの間には大きな相違があることが明らかとな った.ここでエネルギ一損失のうち熱に変換される割合

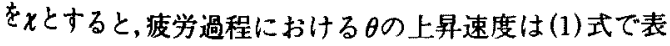

される。

$$
\frac{d \theta}{d t}=\frac{1}{\rho c}\left\{\chi H-H_{D}\right\}=\frac{1}{\rho c}\left\{\chi \pi f \varepsilon_{d}^{2} E^{\prime \prime}-\varkappa \theta\right\}
$$

ここで, Hは簐位時間当たりの粘弾性的エネルギー損失, $H_{D}$ は周囲媒体への放熱速度, $\rho$ は密度, cは比熱, fは周 波数, E”は損失弾性率, $x$ は周囲媒体入の熱伝详係数であ る、 ルには試料の比表面積が含まれている，Hから $H_{H}$ を 差し引いた部分は疲労破壊を引き起こす不可逆的な棈造 変化に曹やされるエネルギー $H_{S}$ に对応すると考えた.す なわち，疲労破壊は不可逆的な構造変化に費やされるエ ネルギー損失があるしきい值，Cに達したときに起こると 考えた，疲学過程における動的粘弾性変化と試料表面温 度の上昇から，(1)式に各変数を代入し $x$ を評価した。だ しxは, 疲労試験中断後の $\theta$ の変化より評洒した. $\mathrm{H}_{\mathrm{S}}$ の疲 労過程中の平均值, $H_{s, a v}$ を求め, 種々の高分子材料の $H_{s, a v}$ と疲労寿命, $t_{f}$ の両対数プロットすると, Fig.2に模式的 に示すように低疲労寿命側での傾きがー1, 高疲労寿命側 である一定值に漸近し，次式が成立した。

$$
\left(\mathrm{H}_{\mathrm{s}, \mathrm{av}}-\mathrm{H}_{0}\right) \mathrm{t}_{\mathrm{f}}=\mathrm{C}
$$

すなわち(2) 式は,Fig.2(b)に示すように疲労過程で構造
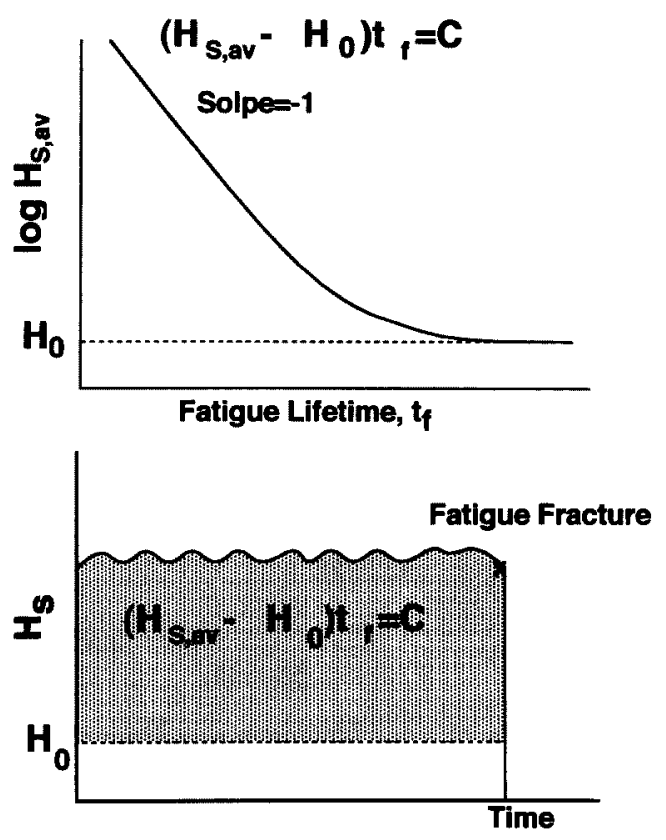

Fig. 2 (a) Schematic representation of the relatioship between average hysteresis loss dissipated for irreversible structural change and fatigue lifetime. (b) Schematic representation of the change of $\mathrm{Hs}$ up to the fatigue failure. 
変化に費やされるエネルギー $H_{s, a v}$ からある一定值, $\mathrm{H}_{0}$ を 差し引いたものの総和がCに達したときに疰労破壊が起こ ることを示す疲労破壊規準式である.Cは疲労破壊までに 構造变化に費やされた有効エネルギー損失の総和， $\mathrm{H}_{0}$ は 疲学限界エネルギー損失である。この式は $\mathrm{p}-\mathrm{PVC}, \mathrm{HDPE}$, PBT, ナイロン6, SPUU, SBSエラストマーに対して成 立することを確認した ${ }^{3 \sim 13)}$. (2)式により, 短時間の非破堙 試験により疲労寿命の定量的予測が可能となった. Fig. 3 は種々の高分子材料の疲労の規集式のC值をまとめたもの である，定数Cはガラス状高分子のp-PVCで最も低く，つ いでナイロン6, PBT, HDPEの順に増大した。これらの 結果は結晶性高分子は結晶の塑性変形などにより外部か らの力学的エネルギーを昅収することができるために耐 疲労性が優れていることを示唆している，またエラスト マーには大変形を加えることができるため，著しく高い C值を示した.またSBSエラストマーとSPUUを比較する と，ハードセクメントが塑性変形でエネルギーを吸収で きるSPUUがガラス状の艖いハードセクメントを有するSBS に比べて高いC值を示した，一方， $H_{0}$ は線形粘弾性限界 の歪み量の大きなエラストマーで高く，その著しく小さ いHDPEの場合、はぼ0の値を示した，HDPEの場合は, 疲労中に歪み振幅を変えた場合にも疲学の規準式が成立 したが，ソフトセグメントのガラス転移温度が著しく低 いSPUUの場合は，疲労被害のhealingが観測された。こ のHealingの問題は分子運動特性が密接に関わっており, 今後検討すべき課題の一つである.

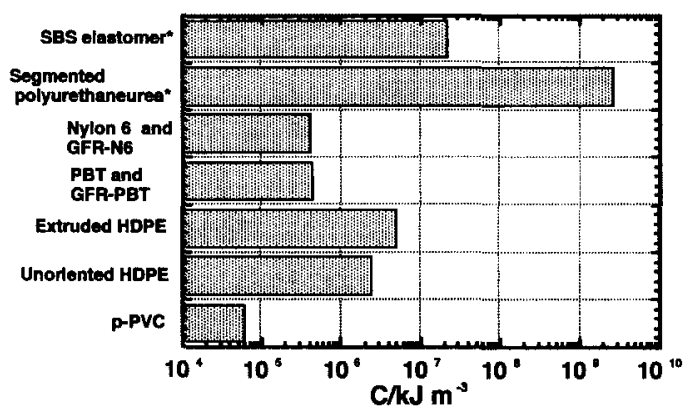

Fig. 3 Values of total hysteresis loss dissipated for irreversible structural change for various polymers.

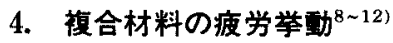

複合材料は種々の構造材料に利用されており，疲労寿 命の予測と酎疲労性の向上は材料の安全性の確立のため に極めて重要である。30 wt\%のガラス短瀻維で強化した
$\mathrm{PBT}^{8)}$ とナイロン $6^{9,109}$ の疲労挙動におよぼすガラス織維表 面処理の影響を検討し，界面の影響を考虑した疲労破埢 規準式を提案した. 表面未処理GF短棫維(SUSGF)で強化 した複合材料は,表面アミノシラン処理GF短㧴維(SMSGF) で強化した複合材料に比へて疲学中の表面温度上㫒は高 く, E’の低下は顕著であった. SUSGFで強化した複合材 料の場合，ガラス維ーマトリクス高分子間の界面相互 作用が弱く，ガラス械維一マトリクス高分子の界面娳踓 が容易に起こる.ガラス臷維の弾性率はマトリクス高分 子に比べて数十倍高いため, 界面别離が起こればマトリ クスに動的歪が集中する.したがってSUSGFで強化した 複合材料のマトリクスに加わる動的歪はSMSGFで強化し た複合材料に比へて大きくなり，高い発熱量を示した。 疲労を中断して試料を液体窒素中で破断し表面を研磨し た試料の走査型電子顕微鏡観察を行った.SUSGFで強化 した複合材料の場合, 界面の接着性が弱く, 短時間で界 面剝離を起こすことが明らかとなった，一方, SMSGFで 強化した複合材料の場合, GF表面がシランカップリンク 剤処理されているため界面の接着は強固であった、GF強 化複合材料に疲労の規準式を適用するために, マトリク スに印加されている真の動的歪振幅を温度上年に基づき 推定した. SUSGFで強化した複合材料の場合, 界面䟝離 のためにマトリクスに均一に動的歪が分布し,SMSGFで 強化した複合材料の場合, GF/マトリクス高分子界面の接 着が強固であるため界面での動的歪はゼロで織維間の中 点で動的歪は最大となるというモデルを仮定した. さら にそのモデルにより評価したマトリクスに印加される動 的歪振幅を用いて (2) 式の複合材料への適用を検討した。 マトリクスに加わる動的坖の分布を考虑することにより， 複合材料でも疲労破壊規準式の適用が可能であった. 分 子複合系である(ナイロン6/モンモりロナイト)複合系で も同様に疲学破壤の規準式が成立した ${ }^{11,12)}$ 。

\section{5. 非線形粘弾性の発現と疲労挙功 ${ }^{15 ~ 20)}$}

疲学破壊が起こる条件下では試料に線形粘弾性限界を 越える動的歪振幅が印加されている. 著しく大きな動的 歪振幅の場合, 非線形粘弾性の発現にともない, みかけ の弾性率の低下, $\tan \delta の$ 増加が観測され, 応答応力波形 の正弦波からのずれが顕著になる.Fig.4は液晶高分子で あるべクトラン維維に大きな正弦的な動的歪を印加した 場合の, 応答応力の正弦波からのずれを示したものであ る.動的歪振幅の増大とともに正弦波からのずれが影著 になり，非線形粘弾性の発現は不可逆的な構造変化と関 連していることが示唆される，種々の高分子材料の疲労 過程における非線形粘弾性变化を連続的に測定し，非線 形粘弾性と疲労挙動の関係について検討した. 非線形性 

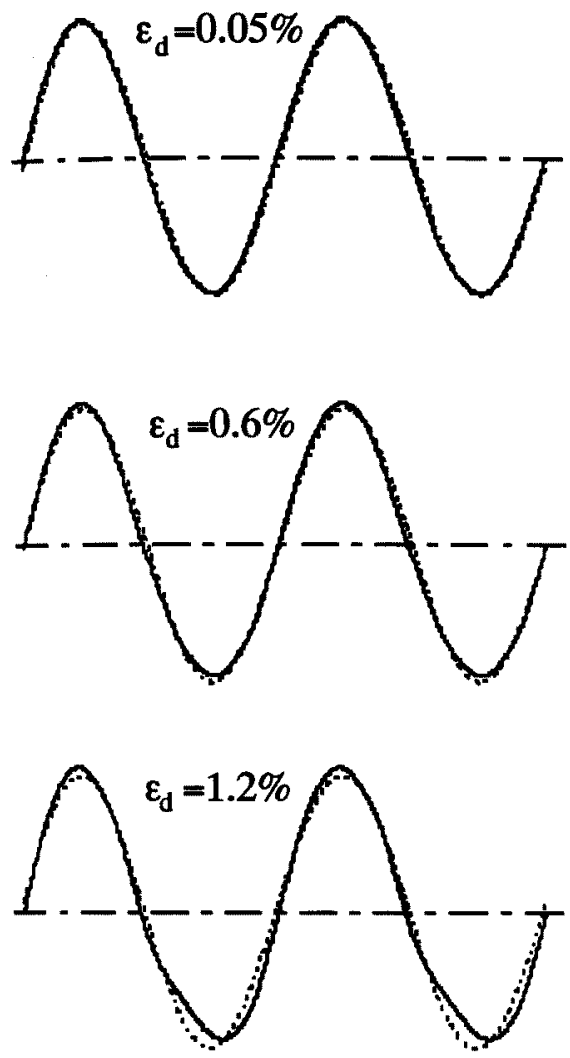

Stress

\section{Strain}

Fig. 4 Strain amplitude dependence of response stress signals of Vectran fiber at $303 \mathrm{~K}$ after 100 $\mathrm{sec}$ from the start of the fatigue testing.

の程度を定量的に評洒するために応答応力のフーリエ解 析を行った，試験片に，周波数，f(角周波数，光)の一定 振幅の正弦的变位を与え、観測される応答応力をフーリ 工級数で表した。

$\sigma(t)=\sigma_{0}+\sigma_{1} \sin \omega t+\sigma_{2} \sin 2 \omega t+\sigma_{3} \sin 3 \omega t+\cdots$

ここで向は応答応力のフーリエ係数である。応答応力波 形のデジタルデータをフーリエ解析し，非線形粘弾性を 定量的に評価するために十次までの高調波成分の振幅の 和と基本波成分の振幅の比より非線形粘弾性パラメータ 一(NVP)を(4)式で定義した。

$$
N V P=\frac{\sigma_{2}+\sigma_{3}+\cdots+\sigma_{10}}{\sigma_{1}}
$$

種々の樴維・高分子材料について疲労寿命とNVPの関 係を検討し, NVPの增大に伴ない疲労寿命が低下するこ
とを䧽測した．これらの事実は疲労現象が非線形粘弾性 の発現と密接に関連していることを示している.またNVP の疲労時間依存性を測定すると，また疲労破堙植前で， NVPが急激に増大寸る疲労破壊の前駆現象が確認でき, 被労の進行が予知できることを明らかにした。

種々の分子鎖の剛直性の異なる高分子瀻維の疲労挙動 と非線形動的粘弾性挙動を比較検討した，分子鎖㴊直性 係数 Z は光弾性測定に基づき評価した，屈曲性分子銷を

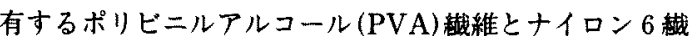
維では㓮直性你数 $Z$ は小さく，剛直性分子銷を有するべ クトラン狨雅とポリパラフェニレンテレフタルアミド(PPTA) 韯維ではZは大きい值を示しな。ポリエチレンテレフタ レート(PET)賳維の分子銷は剛直的な芳香環を含むので, Z は上記二種類の韯維の中間值を示した.Fig.5は種々の 高分子赫維のNVPの動的歪み振幅依存性である。分子銷 㓮直性の增加に伴い，高分子材料の非線形動的粘弾性が 顕著になることが明らかである，微小变形の場合，高分 子材料のNVP値は分子鎖剛直性の增加と共にわずかに增 加した．大変形の場合には，分子鎖㓮直性の增加に伴う 高分子材料のNVP值の著しい增大が観測された，一方， 屈曲性高分子の場合，その屈曲性分子銷から構成された 非晶領域で大変形を容易に吸収できるので, 低いNVP值 を示した，剛直性高分子の場合には，剛值な分子銷は外 部の大変形の歪みを容易に吸収することが期待できず， 分子鎖のすべりなどに起因する不可逆的な凝集構造変化 が起こりやすい。このため, 分子銷剛直性の增加と共に, 高分子㵶維の非線形粘弾性泣顕著になったと考えられる. 高分子截維に強制変形を加えた場合，応答応力は 1 周

Freq. $=11 \mathrm{~Hz}$, Temp. $=303 \mathrm{~K}, \varepsilon_{s}=1.8 \%$

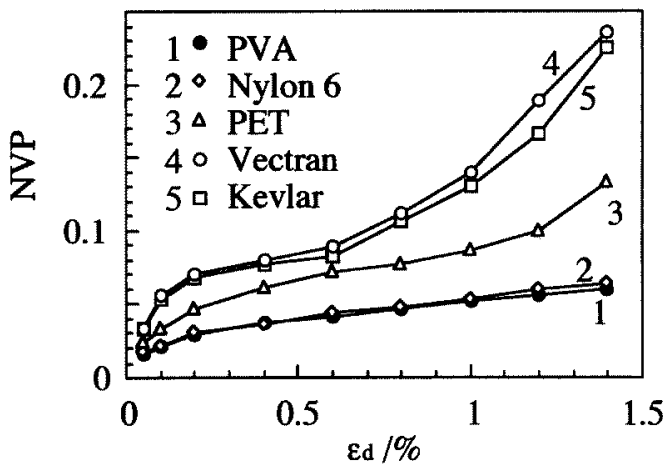

Fig. 5 Strain amplitude dependence of NVP for various polymeric fibers with different chain rigidity at $303 \mathrm{~K}$ after $100 \mathrm{sec}$ from the start of the fatigue testing under static strain of $1.8 \%$. 
期内で応力の增加する変形過程と応力の減少する回復過 程に分けられる。高分子維はその複雑な高次構造のた め,Fig.4に示すように強制変形の変形過程とその強制変 形が回復する回復過程において暴なる韭線形動的粘弾性 挙動を示すと考えら机る。正弦的な動的変位を用いた場 合, 一周期の動的変形過程中に試料の変形速度が異なる 变形領域が存在する，その変形・回復過程と変形速度の 非線形動的粘弹特性に与える影響を検討するために，各 変形過程でのNVPを評洒した，屈曲性のPVA繊維及びナ イロン 6 繊維はNVP值が平均的に低く, 回復過程のNVP

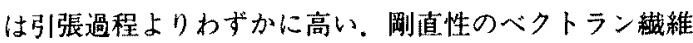
及びPPTA盏維は回復過程のNVPが非常に高いが,引張 過程のNVPは回復過程のそれよりはるかに低い,PET繊 維の分子銷㴊直性は以上に述べた両種類の繊維の中間值 であり，非線形粘弾特性は㴊直性高分子䇅維と屈曲性高 分子韯維の中間的挙動を示した，分子鎖岡值性の低い高 分子に比べて，分子鎖風直性の高い高分子は㓮直性分子 鎖の非昆領域が大変形の動的歪みを昅収することがより 困難となり，特に回復過程では，キンク形成が観察され た.このため，分子鎖剛淔性の增加に伴い，高分子緎維 の回復過程での非線形粘弾性は急激に增加したと考えら れる.

Fig.6は高分子繊維の疲労寿命と分子鎖剛值性係数 Zと の関係である，分子鎖岡直性の増加に伴い，高分子緎維 の疲労寿命が低下した．岡淔性高分子は届曲性高分子の ような分子鎖間の物理的な絡み合いが少なく，大変形の 場合，分子鎖が互いにすべりやすく，不可逆的変形が影 著となる。このため，分子鎖判直性の高い高分子は疲労 過程中における凝集構造の不可逆変化に起因する疲労強

Freq. $=11 \mathrm{~Hz}$, Temp. $=303 \mathrm{~K}, \varepsilon_{s}=1.8 \%, \varepsilon_{\mathrm{d}}=1.4 \%$

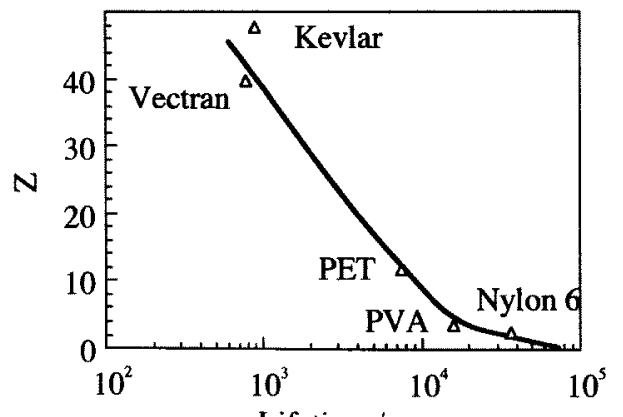

Lifetime /sec.

Fig. 6 Relationship between fatigue lifetime and chain rigidity index, $Z$ under the imposed dynamic strain amplitude of $1.4 \%$ and the static strain of $1.8 \%$.
度の低下が顕著であり，疲労寿命が分子銷剖值性の低い 高分子に比へてはるかに低下したものと考えられる。

以上の上うな樴維高分子材料の非線形動的粘弾性の原 因として，1)応力ー歪曲線の非線形性や非対称性，2）多 相構造に起因する動的歪の不均一な分布，3)破壊に関連 したクレーズやキンクの生成などがあげられる。これら 非線形動的粘弾性は披労現象と密接に関係している。前 述の疲労破壊規準式の構造変化に費やされるエネルギー 損失が，非線形粘弾性の各応答成分とどのように関連し ているかは今後の検討課題の一つである。

\section{6. おわりに}

轼維・高分子材料の披労挙動を材料固有の性質である 非線形動的粘弾性に基づき解析することにより, 疲学寿 命の予知が可能となった。この手法を種々の繊維・高分 子材料に対して適用し，疲労デー夕の蓄積を行えば複合 材料も含めて種々の材料の疲労寿命の予測が可能となり， 耐疲労性䇝維高分子材料の設計, 材料の安全性の向上, 構造材料の軽量化による省エネルキー化にも大きく貢跬 することを確信している。

\section{謝辞}

本研究を行うに当たって、「䋞維・高分子材料の疲労」 の研究テーマに取り組む機会を与えてくださり, またこ 教示いただいた高柳素夫九大名誉教授、梶山千里教授(九 大院・工)に心より感謝いたします。また一緒に研究に萼 わっていただいた共同研究者の皆様に厚く御礼申し上げ ます。

\section{女献}

1) 小林英男, 材料科学, $29,8(1992)$.

2) R. W. Hertzberg J. A. Manson, "Fatigue of Engineering Plastics", 1980, Academic Press.

3) A. Takahara, K. Yamada, T. Kajiyama, M. Takayanagi, J. Appl. Polym. Sci., 25, 597 (1980).

4 ) A. Takahara, K. Yamada, T. Kajiyama, M. Takayanagi, J. Appl. Polym. Sci., 26, 1085(1981).

5) N. Kaiya, M. Kugishima, A. Takahara, T. Kajiyama, 戴維学会誌, 42, T-127(1986).

6 ) N. Kaiya, A. Takahara, T.Kajiyama, Polym. J., 21, 523(1989).

7) 高原 淳, 日本レオロジー学会誌, 23, 217(1995).

8 ) A. Takahara, T. Magome, T. Kajiyama, J. Polym. Sci., Phys. Ed., 32, 839 (1994).

9) A. Yamashita, A. Takahara, T. Kajiyama, Proc. $5^{\text {th }}$ SAMPE Symp., 73 (1997). 
10) A. Yamashita, S. Higashi, S. Komatsu, A. Takahara, T. Kajiyama, Key Eng. Mater., 137, 147 (1998).

11) 山下敦志, 高原 淳, 梶山千里, 日本レオロジ一学 会誌, 24, 117 (1996).

12) A. Yamashita, A. Takahara, T. Kajiyama, Composite Interfaces, 6, 247 (1999).

13）高原 淳, 田下純一，梶山千里，高柳素夫，高分子 諭文集, 39, 203(1982).

14) A. Takahara, J. Tashita, T. Kajiyama, M. Takayanagi, J. Biomed. Mater. Res., 18, 13(1985).

15) A. Takahara, K. Yamada, T. Kajiyama, M. Takayanagi, J. Mater. Sci, 15, 2653 (1981).
16) N.J. Jo, A. Takahara, T. Kajiyama, Polym. J., 25, 721 (1993).

17) N.-J. Jo, A. Takahara, T. Kajiyama, Polym. J., 26, 1027 (1994).

18) N.J. Jo, A. Takahara, T. Kajiyama, Polymer, 38, 5195 (1997).

19) T. Liang, K. Tokunaga, A. Yamashita, A. Takahara, T. Kajiyama, Polym. Bull., 36,477(1996).

20) T. Liang, K. Saito, A. Takahara, T. Kajiyama, Polym. J., 28, 801 (1996).

21) T. Liang, A. Takahara, K. Saito, T. Kajiyama, Polymer, 39, 5387 (1998).

\section{プラスチック成形加エ学会 第46回講演会 \\ ープラスチックフィルム・織維の最新技術と将来一}

日 时：1999年11月26日(金) $11: 10-17: 20$

所：東洋紡績㑣総合研究所，大津市堅田2-1-1(开520-0292)

主 萑: プラスチック成形加工学会

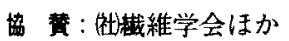

内 客:

(1) $11: 10 \sim 12: 10$

「フィルム成形機\&二軸延伸機の最近の准歩」

三菱重工業晽 竹内 直和

(2) $13: 10 \sim 14: 10$

「フィルム・織成形の解析技術」

出光石油化学株 金井 俊孝

(3) $14: 10 \sim 15: 10$

「フィムム・繊維成形の成形性と新規フィルムの開発」

東洋紡績侏 石原 英昭

(4) $15: 20 \sim 16: 20$

「フィルム成形の解析技術一キャス卜・延伸・巻取」 金沢大学 山田 敏郎

(5)16:20 17:20

「溶融紡糸の最近の技術」

東京工業大学 旗谷 雄士

定 貫: 100名(先着順，定員に達し次第締切)

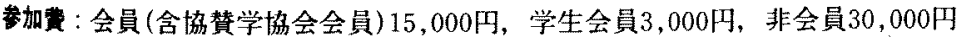

申込み方法：所定の「参加申込書」(コピーも可)に必要事項安記入の上，下記までお申し込み下さい。

ご送金は，銀行振込・郵便為替または現金にてお送り下さい。(ご希望の方には請求書をお送りいなします)

申込み・問合せ先 :

東京都渋谷区桜丘町15-8(テ150-0031)桜丘ビリジアン203

社団法人プラスチック成形加工学会事務局

電涪 : 03-3770-4416, FAX : 03-3770-4417

倭便為替番号 00130-7-402104 